\title{
Nature and Children's Play: Investigation of Child-Nature Interaction in Urban Green Parks
}

\author{
Yasmin Sauer Machado \\ Universidade Federal de Santa Catarina, Florianópolis, SC, Brazil \\ Patrícia Maria Schubert Peres \\ Dayse da Silva Albuquerque \\ Programa de Pós-Graduação em Psicologia da Universidade Federal de Santa Catarina, \\ Florianópolis, SC, Brazil \\ Ariane Kuhnen ${ }^{1}$ \\ Departamento de Psicologia e Programa de Pós-Graduação em Psicologia da Universidade \\ Federal de Santa Catarina, Florianópolis, SC, Brazil
}

\begin{abstract}
Studies have shown that contact with nature brings cognitive, social, physical and psychological benefits to children, influencing their development. In natural environments, children play jumping, running, digging, building, hiding, climbing trees, and develop the capacity of imagination in make-believe play. In the present study, which aimed to understand the child-nature interaction in play, 30 children aged 2 to 10 years were observed in two urban green parks of Florianópolis, southern Brazil (SC). Thus, one observation protocol was developed using the technique of person-centered behavioral mapping. In both contexts, sand was the natural element most used in constructive play. Children were observed gathering sand with plastic shovels or pots to build something. Other elements such as vegetation, water and stone were observed less frequently in play behaviors. In one of the parks, vegetation was used in a turbulent play with a child climbing a tree. Water was used in turbulent play of spreading water and throwing it at one another, and stones were used in constructive play. The preservation of these elements in natural areas or their inclusion in planned areas implies in the expansion of recreational opportunities for children.
\end{abstract}

Keywords: Environmental psychology, child development, play, nature.

\section{Brincadeiras Infantis e Natureza: Investigação da Interação Criança-Natureza em Parques Verdes Urbanos}

\section{Resumo}

Estudos vêm mostrando que o contato com a natureza traz benefícios cognitivos, sociais, físicos e psicológicos para as crianças, influenciando seu desenvolvimento. Nos ambientes naturais as crianças realizam diversos tipos de brincadeiras e desenvolvem a capacidade de imaginação. No presente estudo, com o objetivo de conhecer a interação criança-natureza nas brincadeiras, foram observadas 30 crianças de dois a dez anos em dois parques verdes urbanos de Florianópolis (SC). Para isso, foi elaborado

Mailing adress: Universidade Federal de Santa Catarina, Centro de Filosofia e Ciências Humanas, Departamento de Psicologia, Laboratório de Psicologia Ambiental, sala 11B, Campus Universitário, Trindade, Florianópolis, SC, Brazil 88040-970. Phone: (48) 3721-8574. E-mail: lapamcfh@gmail.com, yasminsm@gmail.com, pmschu@hotmail.com, albuquerquepsi@hotmail.com and ariane@cfh.ufsc.br 
um protocolo de observação e utilizada a técnica de mapeamento comportamental centrado-na-pessoa. Nos dois contextos, a areia foi o elemento natural mais utilizado nas brincadeiras construtivas. Nessas brincadeiras, as crianças juntavam a areia com potes plásticos, pás ou com as próprias mãos a fim de construir algo. Outros elementos da natureza como a vegetação, a água e a pedra foram observados com menor frequência nas brincadeiras. A vegetação foi utilizada em um dos parques em brincadeira turbulenta de subir em árvore. A água apareceu em brincadeiras turbulentas de esparramar água e jogála em outras crianças, e a pedra apareceu em brincadeiras construtivas. Preservar a presença desses elementos em áreas naturais ou inclúi-los em áreas planejadas implica na ampliação de oportunidades de recreação para as crianças.

Palavras-chave: Psicologia ambiental, desenvolvimento infantil, brincadeiras, natureza.

\section{Los Niños y los Juegos de la Naturaleza: La Investigación de la Interacción Niño-Naturaleza en los Parques Verdes Urbanas}

\section{Resumen}

Los estudios han demostrado que el contacto con la naturaleza trae beneficios cognitivos, sociales, físicos y psicológicos para los niños, que influyen en su desarrollo. En ambientes naturales los niños realizan trucos como saltar, correr, construir, esconderse. Con el objetivo de conocer la interacción niñonaturaleza en los juegos, 30 niños de dos a diez años se observaron en dos parques verdes de la ciudad de Florianópolis (SC). Así que un protocolo de observación se desarrolló y utilizó la cartografía técnica conductual centrada en persona. En ambos contextos, la arena era el elemento natural más usado en el juego constructivo. En estos juegos, los niños reunieron la arena con palas de plástico o con sus propias manos, para construir algo. Se observaron otros elementos de la naturaleza como la vegetación, el agua y la piedra con menor frecuencia en los juegos. La vegetación se utilizó en juegos con los árboles, el agua apareció en el juego donde los niños lanzaban el agua en otros niños, y la piedra apareció en el juego constructivo. Preservar la presencia de estos elementos en los espacios naturales o incluirlos en áreas planificadas implica la expansión de las oportunidades de recreación para los niños.

Palabras clave: Psicología ambiental, desarrollo infantil, juego, naturaleza.

Play is considered a global phenomenon that has been present in the everyday life of children of several cultures and has become one of the defining characteristics of childhood (Fiaes \& Bichara, 2009). Additionally, it represents a complex and multifaceted behavior whose most definitions are insufficient (Hansen, Macarini, Martins, Wanderlind, \& Vieira, 2007). There is often no difference between play and other solitary behaviors such as exploring the environment (Pinho, 2004), although it may be easily identified as a visible behavior that generates high levels of activity and is characterized by common features like laughter and relaxation (Yamamoto \& Carvalho, 2002).

The role of play in child development remains unclear, but currently the predominant and most influential conception suggests that it helps in training skills that will be helpful in the future. One can state that, when children play, the means justify the ends (i.e., this does not seem to have an immediate purpose, which may be the most accepted criterion to define play; Santos \& Dias, 2010).

Based on what is known about the importance of play, leisure areas are planned so as to meet children's developmental needs and ensure their safety, with playgrounds being an example of the intent to promote motor challenges (Fjørtoft, Kristorffersen, \& Sageie, 2009). However, activities and areas planned for children do not always correspond to their preferences in the use of a place (Rasmussen, 2004). Studies on place preference show that areas of nature are those 
that children like and use the most when available (Korpela, Kÿtta, \& Hartig 2002; Samborski, 2010; Sargisson \& McLean, 2012; Wells, 2000). This may be explained by the excitement of doing activities in natural environments (Jansson, 2008) or by the lack of parental supervision (Valentine \& McKendrick, 1997).

The presence of nature in leisure open spaces provided a diversity of plays for children to perform. A study by Sargisson and McLean (2012) compared the preferences of 4,597 children younger than 12 years of age in the use of natural and built elements in 56 playgrounds in New Zealand. The results of their study showed that $14 \%$ of the time spent by children in these places involved playing with natural elements, which were used more often by boys than by girls. It was also found that the greater the diversity of natural elements, the higher children's likelihood to use them, and that these elements provide a greater repertoire of play behaviors compared with built elements.

When analyzing interviews conducte with 105 parents, teachers, and managers of 59 schools, Dyment and Bell (2008) found that the variety of vegetation and topography present in schools diversifies the repertoire of children's play behaviors, providing play for boys and girls of all ages, as well as physical exercise. These environments invite children to do several physical activities, such as jumping, running, digging, building, hiding, and climbing up trees. Corroborating with the above research, Azlina and Zulkiflee (2012) state that the resources found in the school environment influence children's physical activity and that natural environments lead to diversified play and learning.

The way children make use of open spaces and the presence of certain elements of nature are also related to the type of play. The presence of vegetation has been associated with constructive, turbulent and symbolic play (Fjørtoft, 2004; Jansson, 2008; Samborski, 2010). The presence of sand, a very common element in playground areas, is related to constructive play (Czalczynska-Podolska, 2014). Topographical elements such as slopes and stones, for example, afford play involving greater physical strenght, such as climbing and sliding (Fjørtoft, 2004). Loose items, e.g. little stones, sticks, leaves, and fruits are also used by children in constructive and make-believe play (Kernan, 2010; Kuh, Ponte, \& Chau, 2013; Malone \& Tranter, 2003; Refshauge, Stigsdotter, \& Petersen, 2013; Schäffer $\&$ Kistemann, 2012). The relationship of children with water was investigated by Said (2008), who identified 83 types of physical, cognitive, and social activities among children who used rivers and streams in a tropical region.

The opportunities of interaction with nature established by children through play bring important benefits to their development. Functional play involving climbing trees, stones, and slopes pose motor challenges for children and stimulate their senses (Fjørtoft, 2004). Constructive and make-believe play in sandboxes, in the middle of the vegetation and with loose elements of nature provide opportunity for both socialization (Czalczynska-Podolska, 2014) and privacy (Samborski, 2010). Moreover, the exposure to green areas have a restorative effect on cognitive activity (Wells, 2000; Wells \& Evans, 2003). Other studies explored the long-term benefits of contact with nature. Prolonged experiences in nature, through environmental education programs or recreational activities, favor the increase of knowledge on the ecology of places and affection towards nature, contributing to the development of pro-environmental attitudes and behaviors (Chawla, 1998, 2007; Collado, Staats, \& Corraliza 2013; Kahn, 2002) and to the appreciation of the presence of nature in urban spaces (Wang, Liu, Pan, Zhao, \& Zhang, 2012).

In urban spaces, where nature is scarce and where more than $50 \%$ of children live (United Nations Children's Fund [UNICEF], 2012), parks gain importance in providing child-nature interaction. With the disorganized growth of cities and the existence of mobility and safety problems in the streets, parents do not allow their children to walk or play outside in open spaces due to the perception of insecurity regarding these spaces (Romero et al., 2001; Timperio, Salmon, Telford, \& Crawford, 2005). Therefore, parents decide to take their children to urban parks, and also to playgrounds and 
schoolyards, places where contact with nature becomes more accessible and where children have the opportunity to do physical activity and play safely.

Considering the benefits that contact with nature may bring to children, it becomes necessary to understand the use of urban parks and the interactions with nature in these spaces. In the present study, this interaction is understood as an intentional action of children to use the properties of an element of nature in their play. Therefore, given the importance of nature in the promotion of play, the present research aimed to characterize how children related to nature when playing in two urban green parks of Florianópolis, southern Brazil, with the purpose of understanding the relationship between the configuration of these spaces and the activities performed by children.

\section{Method}

This descriptive and exploratory study sought to characterize how children use the natural resources of urban green spaces in their play based on the observational method and on the technique of person-centered behavioral mapping. The technique allows for the researcher to have access to children's behaviors in their everyday environment, being thus widely used in studies aiming to characterize the relationship between children and open spaces (Luz \& Kuhnen, 2013; Raymundo, Kuhnen, \& Soares, 2011; Refshauge et al., 2013; Sargisson \& Mclean, 2012).

\section{Participants}

Thirty children (16 boys and 14 girls) aged from 2 to 10 years participated in this study. Fifteen children were observed in each park and selected according to their apparent age and recruited at a point of the park established by the researcher.

\section{Observation Sites}

Data collection took place in two urban parks of Florianópolis, identified as Park 1 and Park 2. Parks were selected by convenience sam- pling based on two criteria: having preserved nature accessible to the visitor and being often visited by families.

Park 1 is located in the downtown Florianópolis and has an area of 22 hectares that combines preserved Atlantic Forest with structures like hiking paths, playground, brooder, kiosks, sports courts, and fenced areas for animals such as rabbits, broad-snouted caimans, turtles, and tortoises. Park 2 is located in the southern part of Florianópolis, distant $24 \mathrm{~km}$ from the city's downtown and has an area of $20 \mathrm{~km}^{2}$ in which there is a freshwater lagoon of nearly $5 \mathrm{~km}^{2}$ and preserved remaining areas of restinga (coastal woodland) of the Atlantic Forest. The leisure facilities of the park include playground, access aisles to the lagoon, hiking areas, and picnic areas.

\section{Data Collection Procedures}

After the project was approved by the Human Ethics Committee of Universidade Federal de Santa Catarina, under protocol no. 17068013.2.0000.0121, naturalistic observations were conducted using the technique of personcentered behavioral mapping, which consists of following the movements and activities of a given individual for a predetermined period of time in the context of the study. For each session of observation, the researcher defines which individual to assess and records his/her behavior and the place where the activities took place (Fernandes \& Elali, 2008). Given that it is an intrusive technique, it is important to establish an adaptation period (Pinheiro, Elali, \& Fernandes, 2008). In the present study, a period of 5 minutes was defined for the familiarization of both the researcher and the observed individual.

Observations were based on the concept of frozen moment in time (i.e., records represented "mental photographs" capturing specific moments of children's activities; Pinheiro et al., 2008). Additionally, observations were taken periodically using the time sampling method. Thus, the behavior of a given individual was observed and recorded at 3-minute intervals for a total 30 minutes of observation (i.e., each child was observed in ten alternating moments, totaling 10 observations per child). 
To identify the place where the child was observed, the parks were divided into sectors, according to the physical characteristics that differentiated one area from another. Park 1 was fragmented into seven sectors: (a) sector 1 (S1) included an area with playground equipment and trees; (b) sector 2 (S2) was a picnic area with tables, benches, and grass; (c) sector 3 (S3) was characterized by an unpaved walking trail surrounded by vegetation; (d) sector 4 (S4) was formed by a lake that attracted animals such as turtles and alligators and a space with rabbits and tortoises, as well as an area with exercise equipment for adults and picnic tables; (e) sector 5 (S5) consisted of the entrance of the park, including its main gate, its headquarters, a lake, trails, and a portion of vegetation; (f) sector 6 (S6) comprised the garden of the park; and (g) sector 7 (S7) was the central area of the park, where there was the administrative building, drinkers, and toilets. An initial point in S7 was established to approach participants and start observation.

Park 2 was divided into four sectors: (a) sector 1 (S1) was formed by an area including the entrance of the park with parking spaces, administrative headquarters, toilets, picnic areas with tables, benches, and playground equipment; (b) sector 2 (S2) was composed by access aisles to a lagoon, surrounded by vegetation; and (c) sector 3 (S3) was characterized by grass and a strip of sand surrounded by the lagoon on one side and by vegetation on another; and (d) sector 4 (S4) covers all the extension of the lagoon. A point to approach participants and start observation was established in S1.

Participants' recruitment took place in the place defined by the researcher in each park sector 7 in Park 1 and sector 1 in Park 2. Firstly, children's guardians were asked to give consent for their child to participate in the study by signing the informed consent form.

It is worth mentioning that, before observations started effectively, an interobserver agreement test was conducted to ensure precision and reliability for the behavioral categories observed and recorded in the study. A minimum of $70 \%$ of interobserver agreement is required when using a set of predetermined categories (Fagundes, 1999). To this end, the same child was observed simultaneously but independently by two observers during a session of 30 minutes. Subsequently, their records were compared to investigate the degree of interobserver agreement. Changes in the protocol were required in some observation sessions for agreement to reach $80 \%$.

\section{Instrument}

The instrument used to record children's behaviors was an observation protocol adapted from Cordazzo, Westphal, Tagliari, Vieira and Oliveira (2008). This protocol included the following categories: (a) the place (sector) of the park where the child was playing at the moment of observation; (b) the type of play developed by the child; and (c) the element of nature being used in the play. Next to categories, there was a blank space to record additional details considered relevant to the research but that were not covered in the previously defined categories.

\section{Data Analysis}

For analysis purposes, the collected data on the sector where the child was playing, the game played by the child and, if applicable, the element of nature were typed into spreadsheets from the statistical software Microsoft Office Excel. These data were quantified to obtain the frequency of each analysis category (types of play, sectors of the park, and elements of nature), and tables and graphs were created to better visualize the results. Data obtained in each park were analyzed separately, in view of their distinct characteristics.

Children's play was categorized into three types of play: constructive, make-believe, or turbulent. Constructive play refers to the handling of objects to create something. Make-believe play occurs when children use their imagination to represent an object with another and may consist of role-playing (mother, father, teacher, superhero, etc.), and turbulent play covers behaviors such as jumping, running, leaping, push- 
ing, pulling, chasing, diving, swimming, and/ or fighting. Thus, turbulent play occurs when children make sudden and vigorous movements and show a joyful facial expression. These categories are not exclusionary, since the child, for example, may be building a castle (constructive play) while pretending to be a princess (makebelieve play). In these cases, the two categories were simultaneously indicated in the protocol (Cordazzo et al., 2008).

The elements of nature could be stones, sand, animals, vegetation, and water. The category vegetation covered the following natural components: trees, twigs, leaves, flowers, and seeds. It is important to emphasize that the interaction with these elements was noted in the observation protocol only when the child incorporated these components into play and was touching or holding them with the hands.

\section{Results}

The Results section is organized as follows: firstly, results obtained in Park 1 are presented, and then those obtained in Park 2. Our results describe how children occupied the sectors of the parks, which type of play they performed, and which type of play involved interaction with elements of nature.

\section{Park 1}

A total of 147 behaviors were recorded in the seven sectors of the park. Of the 15 children observed in Park 1, nine went to S4, which had a lake and a space with animals, when entering the park. In addition to being the sector to which children went first, S4 was the most occupied, with 64 occurrences. The second most occupied sector was S1, with 47 occurrences, followed by S3, with 28. With seven occurrences, the central sector of the park (S7) was the fourth most used by children, and the less used sector was the one with the picnic area (S2), with only one occurrence. S5, which was the entrance of the park, and S6, delimited by the garden, were not used by children. The lack of use of these sectors may be explained by the fact that S5 is located in the entrance of the park whereas the observers re- mained inside the park, in the central area. This implies that, if children used S5 to enter the park, this behavior was not observed. Additionally, it was not observed whether participants used this sector to leave the park, because the 30 minutes of observation ended before participants went away. S6 was not used because it was surrounded by fences and was closed at weekends, period when the observations took place.

Figure 1 shows the distribution of children's play behaviors according to the three types of play. The predominant type of play was the turbulent one, with 39 occurrences, representing $80 \%$ of observations. Turbulent play was conducted mainly in S1 - 23 occurrences - using built elements of the playground, such as seesaw, swing, and slide, and in S4, with 11 occurrences, including ball games and the use of adult exercise equipment. In addition to these sectors, three turbulent play behaviors were observed in S7, involving jumping obstacles, running and playing in swings, and two in S3, characterized by running and going down slopes.

The second most frequent play behavior was constructive play, with eight occurrences, and involved painting coloring books, building a cup with cardboard, making sand piles, and playing with soap bubble. Three occurrences of constructive play were observed in S1, the playground area, and five occurrences in S4, the lake area. Make-believe play behaviors had two occurrences and were played with toys brought from home (doll, helicopter, and disk), with the child fantasizing that these toys flew. One occurrence of make-believe play was observed in S1 and another in S4.

Of the 49 play behaviors observed, only four involved interaction with nature, all of them in S1, consisting of two turbulent play behaviors and two constructive play behaviors The natural element "vegetation" was used in one of the turbulent play behaviors, which involved climbing a tree. The natural element "sand" was used in other form of turbulent play, in which the participant dragged on the sand. This element was also used in two constructive play behaviors in which a child made a sand pile. 


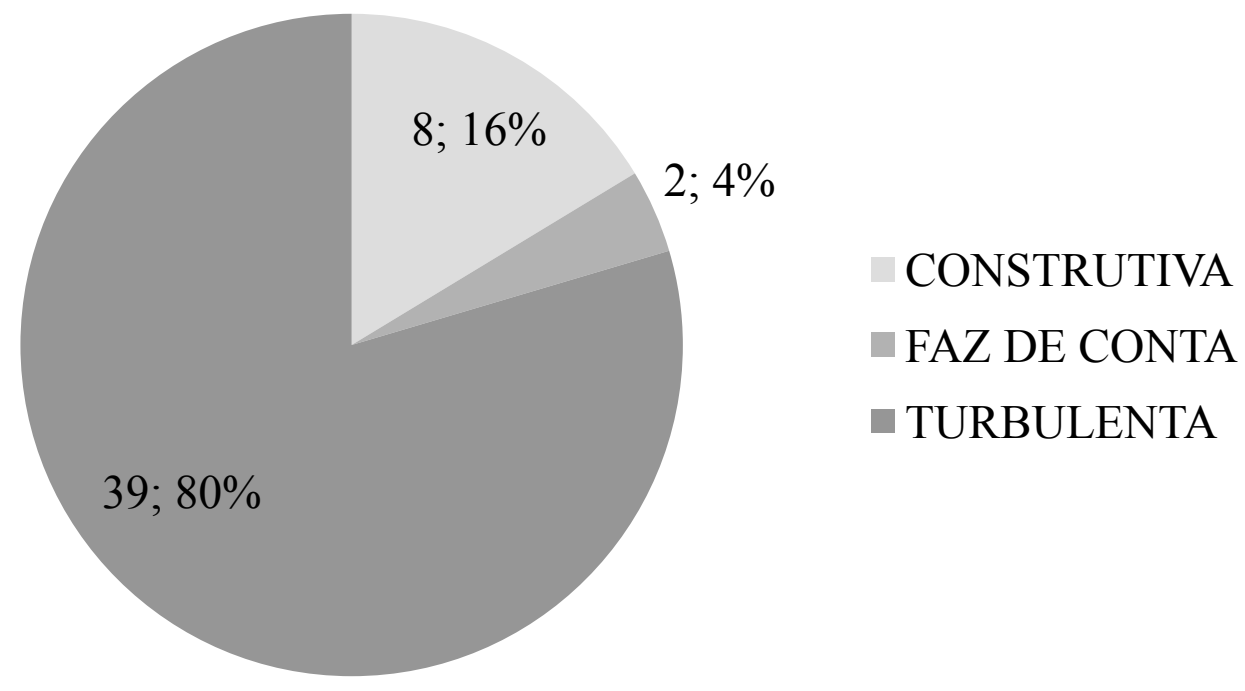

Figure 1. Types of play performed by children/Park 1.

\section{Park 2}

In Park 2, 150 behaviors were observed in the four sectors of the place. The most occupied sector was S4, the lagoon area, with 99 occurrences. S3 was the second most occupied sector, with 46 occurrences, followed by S1, the picnic area, with five occurrences. S2, characterized by the access aisles to the lagoon, had no occurrence. Since participants were recruited at the entrance of the park and the five initial minutes were used to make an adaptation between researcher and subject, no occurrence was recorded in S2.

The play behaviors that occurred the most were those of the turbulent type, with 47 occur- rences, as shown in Figure 2. Of these, 44 were played in S4 and involved activities such as swimming, running, jumping, and diving. The three remaining turbulent play behaviors occurred in S1 and S3. In S1, two turbulent play behaviors were played using the playground equipment, and in S3 there was a child shaking a kayak paddle in the air.

With 13 occurrences, constructive play was the second type of play most performed by children. Eight of these occurrences were observed in S4 and five in S3. The less common type of play was the make-believe one, accounting for $5 \%$ of the play behaviors observed, with one occurrence in S3 and two occurrences in S4.

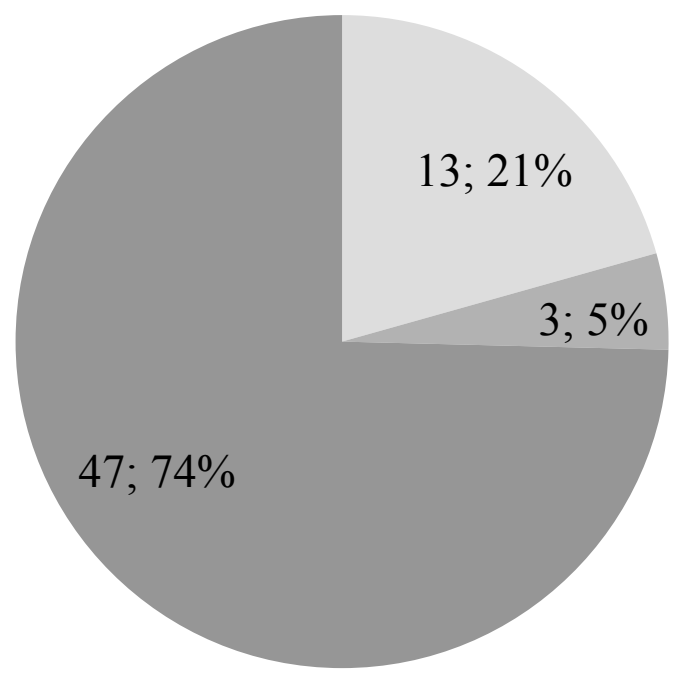

CONSTRUTIVA

FAZ DE CONTA

- TURBULENTA

Figure 2. Types of play performed by children/Park 2. 
Of the 63 play occurrences, 25 involved elements of nature, which were used in all constructive and make-believe play behaviors. The most frequent type of play was the constructive one, with 13 occurrences, followed by turbulent play, with five occurrences, and make-believe play, with three occurrences.

As shown in Figure 3, the most used element of nature in play behaviors was sand. This element was used in ten occurrences of constructive play, one occurrence of turbulent play, and two occurrences of make-believe play. Constructive play was observed in S3 and S4 and consisted of activities such as collecting sand with plastic pots and shovels or with hands to build something. The turbulent play behavior involved a "sand fight" in which children played of throwing sand at each other in S4. The two make-believe play behaviors also occurred in S4 and involved the building of a sand pile in the form of a cake - representing also a constructive play - and the simulation that sand was sunscreen by rubbing it in the arms.

The second element of nature most used in play was water, with the occurrence of four turbulent play behaviors and four constructive play behaviors, one of which occurred together with the element sand. Turbulent play occurred in S4 and consisted of "water fights" - with the use of toy water pistols - and swinging hands and feet to spread water. Constructive play was observed in S3 and S4 and involved the attempt of creating water waves using plastic pots or not. With four occurrences, the natural element stone - the third and last element used by children in Park 2 - was used in S4. Stones were used together with sand in constructive play, since children were observed depositing sand on stones, and in one make-believe play.

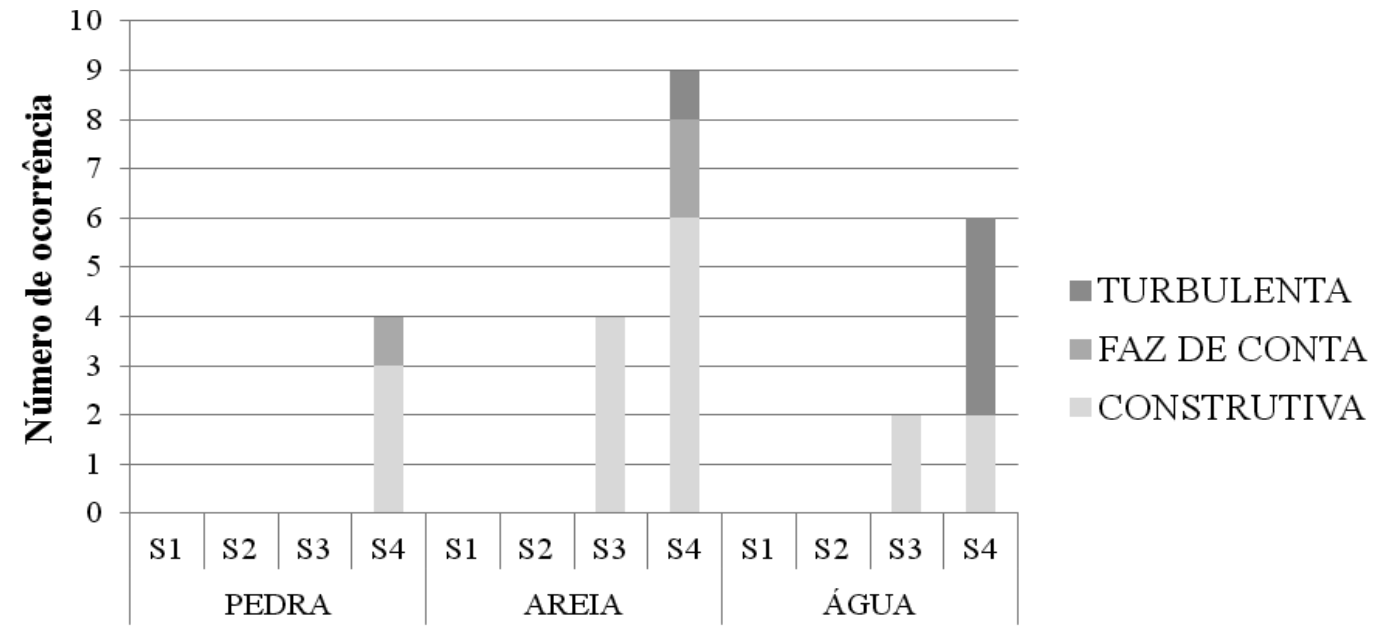

Flementos natureza

Figure 3. Play behaviors using elements of nature in Park 2.

\section{Discussion}

Sand was the natural element most used in children's constructive play behaviors in the two parks. In Park 2, sand was the only natural element used in the three types of play behaviors, mostly the constructive one, followed by turbulent and make-believe play behaviors, which had an approximately equivalent number of occurrences. In observations taken by Refshauge et al. (2013), constructive play was the most common type of play performed by children in the sand space of four public playgrounds in Denmark, followed by functional play behaviors and games.

The presence of sand in the three types of play in Park 2 is probably related to the physical characteristics of the place. As opposed to Park 1 , where sand was limited to a sandbox as part of the equipment on the playground, in Park 2 sand represented a natural resource of a restinga area (i.e., was available to children throughout the park). In this sense, it can be inferred that the natural presence of elements of nature in certain 
areas shows the unplanned potential of these areas to provide play for children.

The second most used element was water. The interaction with this element was only observed in Park 2. Although there were two lakes in Park 1, no interactions between children and water were observed. This possibly results from some characteristics of these lakes, which were built to house reptiles and water birds. The presence of low walls around the lake and the unevenness between ground and water surface creates a spatial barrier that makes it difficult for visitors to access water, allowing them to only observe the place. This type of spatial arrangement promotes a type of behavior among visitors (i.e., using the lakes to observe animals and enjoy the landscape). It is important to emphasize that the presence of water in the composition of landscapes is associated with individuals' psychological repair and well-being (Velarde, Fry, \& Tveit, 2007).

Conversely, water was easily accessible to the visitors of Park 2. In this park, water was provided by a natural lagoon that is an inviting place to bathe during the summer and is considered one of the most important watering places in Florianópolis. In other words, the structure of the park invites its visitors to experience the lagoon, which occurs more effectively in the summer because of the high temperatures. Located in S4 of Park 2, water was used by children in constructive and turbulent play, with an equal number of occurrences. The study by Refshauge et al. (2013) corroborates these findings on and reinforces that play behaviors involving this element favor interaction and cooperation between children.

According to Said (2008), water can also help in the development of sensory, cognitive, physical and social functions. A researcher who observed ten children from 4 to 12 years of age in five creeks and rivers in Malaysia found that water enabled fifteen different activities, including swimming, diving, spreading water, walking, running, and floating. Most activities involved turbulent play behaviors, which were also observed in the interactions of children with water in Park 2. In the present study, it is worth mentioning play behaviors that consisted of spreading water with hands and feet.

The third most used elements were stones, which, similarly to water, only occurred in Park 2. Stones were found next to and inside the lagoon and were more used in constructive play. This result differs from those of studies by Fjørtoft (2004) and Sandseter (2009) conducted in Norway with children from 4 to 7 years, which observed that stones found in the topography of forest areas enabled turbulent play behaviors such as climbing and jumping. However, an investigation by Samborski (2010) on the preferences and perceptions about the type of school ground among 349 children from 6 to 13 years old attending two schools in Canada showed that stones enabled the three types of play behaviors. Children can climb stones (turbulent play), stacking them (constructive play), and do activities requiring imagination, such as using the stone as a fort in spying play or playing house (make-believe playing). Additionally, the author found that this element was also used for children to perform more calm and introspective activities like sitting. Thus, differences in the characteristics of stones allow for different types of interactions. Small loose stones may be thrown in the water and used in constructive play, whereas big stones suggest other possible play behaviors. The location of stones in the environment, their height, and easiness of access to this element may also have an influence on the way stones will be included in children's play behaviors.

The last element used in play behavior was vegetation. Jansson (2008) showed that playgrounds with trees were the preferred playing environment among children, because these elements allow for turbulent play behaviors, such as climbing, and constructive play behaviors, such as building huts. Refshauge et al. (2013) observed the occurrence of turbulent and makebelieve play in a group of 8- to 9-year-old girls who climbed on a tree and tied their jackets to tree branches to be used as a hammock for their teddy bears. Sargisson and McLean (2012) investigated 4,597 children's behaviors in 56 
parks in New Zealand and found that both boys and girls climbed trees, although $76 \%$ of trees were not accessible to children. The authors found that, in addition to being used in climbing, trees provide shadow and, in different periods of the year, let leaves, flowers, nuts, and other seeds fall to the ground, elements that may be used in make-believe playing.

In the present study, the interaction with vegetation occurred only in Park 1. Although Park 2 had dense vegetation, this element was not incorporated into children's playing behaviors. This may be explained by the time of the year during which the study was conducted: summer months. In this period, the lagoon in Park 2 becomes a watering place and vegetation is used as a shelter and resting place, especially for caregivers who monitor children's activities.

\section{Conclusions}

The natural elements that appeared in children's playing were: sand, water, stones, and trees. Sand was the element with which children interacted the most, being the only element used in the two parks and that enabled the three types of play behaviors. In this sense, it is worth emphasizing the importance of maintaining the presence of sand in natural areas or including it in planned areas, considering the influence of sand on children's recreational activities.

Water provided children the opportunity to perform constructive and turbulent play behaviors in an equal number of occurrences in only one of the parks. Stones enabled constructive and make-believe play, mostly the first, only in Park 2. Trees enabled turbulent play in Park 1. Indirect interaction with animals, which was not considered as play because there was no hand contact, was observed in the two parks.

The differences found between the parks with regard to the frequency of interaction with nature possibly result from the physical characteristics of spaces. In Park 1, the presence of physical barriers limited the interaction of children with water and the presence of sand only in the playground area restricted its use. In Park 2, sand was an unplanned element present throughout the park, providing a greater diversity of play. In addition, water was also an accessible resource in Park 2 due to the presence of a lagoon with good swimming conditions, which increased the interaction of children with this natural element.

We conclude that, when accessible, nature is incorporated into children's play. The present study, as well as previous literature, identified several play behaviors with elements of nature, which shows that, in many open spaces such as urban parks, nature plays a leisure role, in addition to esthetic and ecological roles. Depending on their specific characteristics, natural resources such as sand, water, stones, and trees may be incorporated into the planning of children's leisure spaces so as to promote diversity in their play behaviors, whether of the turbulent, constructive, or make-believe type.

\section{References}

Azlina, W., \& Zulkiflee, A. S. (2012). A pilot study: The impact of outdoor play spaces on kindergarten children. Procedia - Social and Behavioral Sciences, 38, 275-283. doi:10.1016/j. sbspro.2012.03.349

Chawla, L. (1998). Significant life experiences revisited: A review of research on sources of environmental sensitivity. Journal of Environmental Education, 31, 15-26. doi:10.1080/00958969809599114

Chawla, L. (2007). Childhood experiences associated with care for the natural world: A theoretical framework for empirical results. Children, Youth and Environments, 17(4), 144-170. Retrieved from http://www.jstor.org/discover/10.7721/ chilyoutenvi.17.4.0144

Collado, S., Staats, H., \& Corraliza, J. A. (2013). Experiencing nature in children's summer camps: Affective, cognitive and behavioural consequences. Journal of Environmental Psychology, 33, 37-44. doi:10.1016/j.jenvp.2012.08.002

Cordazzo, S. T. D., Westphal, J. P., Tagliari, F. B., Vieira, M. L., \& Oliveira, A. M. F. (2008). Metodologia observacional para o estudo do brincar na escola. Avaliação Psicológica, 7(3), 427-438. Recuperado em http://www.redalyc. org/pdf/3350/335027185014.pdf 
Czalczynska-Podolska, M. (2014). The impact of playground spatial features on children's play and activity forms: An evaluation of contemporary playgrounds'play and social value. Journal of Environmental Psychology, 38, 132-142. doi:10.1016/j.jenvp.2014.01.006

Dyment, J. E., \& Bell, A. C. (2008). Grounds for movement: Green school grounds as sites for promoting physical activity. Health Education Research, 23(6), 952-962.

Fagundes, A. J. F. M. (1999). Descrição, definição e registro de comportamento (12. ed.). São Paulo, SP: EDICON.

Fernandes, O. S., \& Elali, G. A. (2008). Reflexões sobre comportamento infantil em um pátio escolar: $\mathrm{O}$ que aprendemos observando as atividades das crianças. Paidéia (Ribeirão Preto), 18(39), 4152. doi:10.1590/S0103-863X2008000100005

Fiaes, C. S., \& Bichara, I. D. (2009). Brincadeiras de faz de conta em crianças autistas: Limites e possibilidades numa perspectiva evolucionista. Estudos de Psicologia (Natal), 14(3), 231-238. doi:10.1590/S1413-294X2009000300007

Fjørtoft, I. (2004). Landscape as Playscape: The effects of natural environments on children's play and motor development. Children, Youth and Environments, 14(2), 21-44. Retrieved from http://www.jstor.org/stable/10.7721/chilyouten vi.14.2.0021?seq=1\#page_scan_tab_contents

Fjørtoft, I., Kristoffersen, B., \& Sageie, J. (2009). Children in schoolyards: Tracking movement patterns and physical activity in schoolyards using global positioning system and heart rate monitoring. Landscape and Urban Planning, 93, 210-217. doi:10.1016/j.landurbplan.2009.07.008

Hansen, J., Macarini, S. M., Martins, G. D. F., Wanderlind, F. H., \& Vieira, M. L. (2007). O brincar e suas implicações para o desenvolvimento infantil a partir da psicologia evolucionista. Revista Brasileira de Crescimento e Desenvolvimento Humano, 17(2), 133-143. Recuperado em http://pepsic.bvsalud.org/pdf/ rbcdh/v17n2/14.pdf

Jansson, M. (2008). Children's perspectives on public playgrounds in two Swedish communities. Children, Youth and Environments, 18(2), 88-109. Retrieved from http://www.colorado. edu/journals/cye/18 2/18 204 SwedishPlaygrounds.pdf
Kahn, P., Jr. (2002). Children's affiliations with nature: Structure, development, and the problem of environmental generational amnesia. In P. H. Kahn Jr. \& S. R. Kellert (Eds.), Children and nature: Psychological, sociocultural, and evolutionary investigations (pp. 93-116). Cambridge, MA: The Massachusetts Institute of Technology Press.

Kernan, M. (2010). Outdoor affordances in early childhood education and care settings: Adult's and children's perspectives. Children, Youth and Environments, 20(1), 152-177. Retrieved from http://www.jstor.org/discover/10.7721/chilyoutenvi.20.1.0152

Korpela, K., Kÿtta, M., \& Hartig, T. (2002). Restorative experience, self-regulation, and children's place preferences. Journal of Environmental Psychology, 22, 387-398. doi:10.1006/ jevp.2002.0277

Kuh, L. P., Ponte, I., \& Chau, C. (2013). The impact of a natural playscape on young children's play behaviors. Children, Youth and Environments, 23(2), 49-77. Retrieved from http://www.jstor. org/discover/10.7721/chilyoutenvi.23.2.0049

Luz, G. M., \& Kuhnen, A. (2013). O uso dos espaços urbanos pelas crianças: Explorando o comportamento do brincar em praças públicas. Psicologia Reflexão e Crítica, 26(3), 552-560. doi:10.1590/ S0102-79722013000300015

Malone, K., \& Tranter, P. (2003). Children's environmental learning and the use, design and management of schoolgrounds. Children, Youth and Environments, 13(2), 1-45. Retrieved from http://www.jstor.org/discover/10.7721/chilyoutenvi.13.2.0087

Pinheiro, J. Q., Elali, G. A., \& Fernandes, O. S. (2008). Observando a interação pessoa-ambiente: Vestígios ambientais e mapeamento comportamental. In J. Q. Pinheiro \& H. Günther (Eds.), Métodos de pesquisa nos estudos pessoa-ambiente (pp. 75-104). São Paulo, SP: Casa do Psicólogo.

Pinho, L. F. S. V. (2004). A agressividade e o conflito nas brincadeiras entre crianças em situação de risco social (Dissertação de mestrado, Universidade Católica de Goiás, Goiânia, GO, Brasil).

Rasmussen, K. (2004). Places for children-children's places. Childhood, 11(2), 155-173. doi:10.1177/0907568204043053

Raymundo, L. S., Kuhnen, A., \& Soares, L. B. (2011). O espaço aberto da educação infantil: 
Lugar para brincar e desenvolver-se. Psicologia em Revista, 16, 251-270. doi:10.5752/P.1678$9563.2010 \mathrm{v} 16 \mathrm{n} 2 \mathrm{p} 251$

Refshauge, A. D., Stigsdotter, U. K., \& Petersen, L. S. (2013). Play and behavior characteristics in relation to the design of four Danish public playgrounds. Children, Youth and Environments, 23(2), 22-48. Retrieved from http://www.jstor. org/stable/10.7721/chilyoutenvi.23.2.0022

Romero, A. J., Robinson, T. N., Kraemer, H. C., Erickson, S. J., Haydel, F., Mendozo, F., \& Killen, J. D. (2001). Are perceived neighborhood hazards a barrier to physical activity in children? Archives of Pediatrics \& Adolescent Medicine, 155, 1143-1148. doi:10.1001/archpedi.155.10.1143

Said, I. (2008). Evaluating affordances of streams and rivers pertaining to children's functioning in natural environments. Journal of King Saud University-Architecture and Planning Division, 20. Retrieved from http://eprints.utm. my/3738/1/river_affordances.pdf

Samborski, S. (2010). Biodiverse or Barren School Grounds: Their effects on children. Children, Youth and Environments, 20(2), 67-115. Retrieved from https://dspace.library.uvic.ca:8443/ bitstream/handle/1828/4336/20_2_04_BiodiverseOrBarren.pdf? sequence $=1 \& \overline{\text { is }}$ Allowed $=y$

Sandseter, E. B. H. (2009). Affordances for risky play in Preschool: The importance of features in the play environment. Early Childhood Education Journal, 36, 439-446.

Santos, A. K., \& Dias, A. M. (2010). Comportamentos lúdicos entre crianças do nordeste do Brasil: Categorização de brincadeiras. Psicologia: Teoria e Pesquisa, 26(4), 585-594. Recuperado em http://www.scielo.br/pdf/ptp/v26n4/02.pdf

Sargisson, R. J., \&. McLean, I. G. (2012). Children's use of nature in New Zealand playgrounds. Children, Youth and Environments, 22(2), 144163. Retrieved from http://www.colorado.edu/ journals/cye/22_2/22_2_07_NewZealandPlaygrounds.pdf

Schäffer, S. D., \& Kistemann, T. (2012). Reconceptualizing school design: Learning environments for children and youth. Children, Youth and Environments, 22(1), 270-279. Retrieved from http://www.jstor.org/discover/10.7721/chilyoutenvi.22.1.0270
Timperio, A., Salmon, J., Telford, A., \& Crawford, D. (2005). Perceptions of local neighborhood environments and their relationship to childhood overweight and obesity. International Journal of Obesity, 29, 170-175. doi:10.1038/ sj.ijo.0802865

United Nations Children's Fund. (2012). Situação mundial da infância 2012: Crianças em um mundo urbano (Report). Retrieved from http://www. unicef.org/brazil/pt/PT-BR_SOWC_2012.pdf

Valentine, G., \& McKendrick, J. (1997). Children's outdoor play: Exploring parental concerns about children's safety and the changing nature of childhood. Geoforum, 28(2), 219-235. Retrieved from http://ynckelowna.weebly.com/ uploads/1/3/2/0/13208868/childrens_outdoor_ play.pdf

Velarde, M. D., Fry, G., \& Tveit, M. (2007) Health effects of viewing landscapes: Landscape types in environmental psychology. Urban Forestry \& Urban Greening, 6(4), 199-212. Retrieved from http://www.friskinaturen.org/media/landscape_ viewing..._2_bs.pdf

Wang, F., Liu, J., Pan, B., Zhao, L., \& Zhang, M. (2012). Stuck between the historic and modern China: A case study of children's space in a hutong community. Journal of Environmental Psychology, 32(1), 59-68. doi:10.1016/j. jenvp.2011.10.001

Wells, N. M. (2000). At home with nature: Effects of "greenness" on children's cognitive functioning. Environment and Behavior, 32(6), 775-795. doi:10.1177/00139160021972793

Wells, N. M., \& Evans, G. W. (2003). Nearby nature: A buffer of life stress among rural children. Environment and Behavior, 35(3), 311-330. doi:10.1177/0013916503035003001

Yamamoto, M. E., \& Carvalho, A. M. A. (2002). Brincar para quê? Uma abordagem etológica ao estudo da brincadeira. Estudos de Psicologia (Natal), 7(1), 163-164. Recuperado em http:// www.redalyc.org/articulo.oa? $\mathrm{id}=26170116$

Recebido: 21/11/2014

$1^{a}$ revisão: $14 / 05 / 2015$ Aceite final: 10/06/2015 